\title{
PEMANFAATAN IKAN UNTUK INISIASI USAHA MAKANAN PADA ANAK-ANAK YAYASAN PANTI ASUHAN BUMI NUSANTARA KOTA BENGKULU
}

\section{FISH PROCESSING FOR FOOD BUSINESS INITIATION ON YAYASAN PANTI ASUHAN BUMI NUSANTARA BENGKULU CITY}

\author{
Oleh: \\ Nyayu Neti Arianti, Melli Suryant' \\ Jurusan Sosial Ekonomi Pertanian, Fakultas Pertanian, Universitas Bengkulu \\ Email: nnarianti@unib.ac.id
}

\begin{abstract}
This activities aimed to: 1) to apply knowledge and skills about processing fish into a variety of food (pempek, fish nugget and fish balls) to girls in the orphanage, and 2) to evaluate those knowledge and skills from production, economic and prospective aspect. Activity method included counseling to transfer knowledge about how to process fish into healthy food worth selling is Learning by Doing method so that science and skill more easily understood. Evaluation of known science and skill was done by descriptive method. This activites were very interesting for participants because the science and skills that were shared easily implemented. All participants were enthusiastic. The 23 participants were divided into three groups. The first group maked pempek, the second group maked fish nuggets and the third group maked fish balls. The evaluation of the initiation activities of this fish processing business indicated that the knowledge and skill that was applied, ie from the aspect of production (easy to do) was expressed by $94.4 \%$ of participants, from economic aspect (feasible and profitable) was expressed by $100 \%$ participants, and from the aspect of prospective (the initiation of this effort aspired to be realized into a home business) was expressed by $100 \%$ of participants.
\end{abstract}

Keywords: fish processing, food, business initiation, orphanage

\section{PENDAHULUAN}

Berbagai program ketahanan pangan dan penuhan gizi nasional telah digalakkan oleh pemerintah beberapa tahun terakhir. Salah satu program tersebut adalah GEMARIKAN (Gerakan Memasyarakatkan Makan Ikan). Ikan merupakan sumber protein hewani yang sangat dibutuhkan tubuh (Putry, 2016). Protein terdiri dari beberapa asam amino, yang mana sebagian dapat diproduksi oleh tubuh dan sebagian lagi tidak (http://gizi.depkes.go.id, 2013).

Berbagai makanan hasil olahan ikan pun berkembang pesat. Usaha kuliner olahan ikan juga sangat diminati konsumen. Ikan dapat diolah dengan mudah dan murah. Pengolahan ikan menjadi berbagai makanan ringan dapat dilakukan oleh berbagai kalangan, baik orang dewasa maupun anak-anak. Dibandingkan dengan protein dari tumbuhan, protein hewani seperti daging, ikan, susu, keju, dan telur mengandung semua 9 asam amino essensial yang diperlukan tubuh. 
Makanan hasil olahan ikan yang mudah dibuat adalah pempek, nugget ikan dan bakso ikan. Makanan ini sangat digemari oleh semua kalangan usia. Salah satu jenis usaha yang dapat menjadi pilihan ketika memulai atau merintis suatu usaha adalah usaha kuliner olehan ikan. Usaha kuliner olahan ikan dapat menjadi usaha bisnis yang menjanjikan, karena digemari masyarakat dan bahan bakunya banyak tersedia (http://infoagribisnis.com, 2017).

Banyaknya variasi makanan dari olahan ikan membuka peluang bagi masyarakat sebagai sumber pendapatan ataupun sebagai tambahan penghasilan keluarga. Begitu pula yang dialami Yayasan Panti Asuhan Bumi Nusantara Kota Bengkulu. Yayasan Panti Asuhan Bumi Nusantara yang beralamat di Jl. Gading Cempaka RT 18 RW 02 Kel. Penurunan Kec. Ratu Samban Kota Bengkulu menaungi sebanyak 47 anak yatim piatu, anak yatim, anak piatu, dan anak-anak dari keluarga tidak mampu. Sebagian besar dari anak-anak panti ini adalah anak perempuan. Anak-anak ini berada dalam rentang usia Sekolah Dasar sampai Sekolah Menengah Atas. Setelah pulang sekolah, umumnya mereka mempunyai banyak waktu luang. Waktu luang jika dimanfaatkan dengan baik maka dapat memberikan nilai produktif bagi penghuni panti asuhan dan sebagai income generated bagi pihak yayasan.

Selama ini, biaya operasional panti asuhan hampir seluruhnya diperoleh dari sumbangan para donatur dan bantuan pemerintah, yakni Departemen Sosial. Kegiatankegiatan peningkatan keterampilan bagi anak-anak panti selain bermanfaat untuk mengisi waktu luang, juga meningkatkan kerjasama antar anak-anak, menjadikan anak-anak lebih cerdas dan mandiri, serta menjadi dapat menjadi sumber pendapatan. Menurut Khoirunnisa dkk (2015) pemenuhan hak dan kebutuhan pendidikan anak di panti asuhan belum maksimal dikarenakan seringkali terbentur dengan masalah pendanaan dari donatur yang tidak tetap, disisi lain anak panti juga seringkali mengalami kekurangan perhatiam dan kasih sayang dikarenakan jumlah pengasuh di panti yang hanya sedikit sehingga pendidikan anak panti seringkali tertinggal dibanding anak seusia mereka yang mengalami pengasuhan di dalam keluarga.

Tujuan kegiatan ini adalah untuk mengenalterapkan ilmu pengetahuan dan keterampilan mengolah ikan menjadi berbagai makanan (pempek, bakso ikan dan nugget ikan), dan mengevaluasi keterampilan yang dikenalterapkan tersebut. Manfaat kegiatan ini adalah keterampilan yang dimiliki anak-anak penghuni panti asuhan diharapkan nantinya dapat menjadi soft skill bagi mereka kemudian hari. Selain itu, kegiatan ini dapat menjadi cikal-bakal usaha produktif dan menjadi alternatif sumber pemasukan pendapatan bagi panti.

\section{METODE PENGABDIAN}

Kegiatan ini diperuntukkan bagi anak-anak Yayasan Panti Asuhan Bumi Nusantara Kota Bengkulu. Khalayak sasaran ini ditentukan berdasarkan pertimbangan bahwa anakanak panti asuhan ini berjumlah cukup banyak, yakni sekitar 43 orang. Mereka berusia antara 7-18 tahun. Sebagian besar adalah anak perempuan, yakni 23 orang. Mereka memiliki potensi untuk mengembangkan pengetahuan dan keterampilan terutama untuk hal-hal praktis, mudah, murah, bermanfaat dan aplikatif dalam kehidupan sehari-hari. 
Metode kegiatan yang digunakan dalam kegiatan ini adalah:

1. Penyuluhan

- Memberikan penyuluhan tentang latar belakang, tujuan, manfaat, dampak, teknik, kendala dan peluang keberhasilan memanfaatkan potensi yang dimiliki oleh anak-anak panti asuhan dalam mengelola suatu usaha ekonomi mandiri.

- Mentransfer pengetahuan dan keterampilan tentang mengolah ikan menjadi aneka makanan ringan (pempek, bakso dan nugget) yang layak jual.

2. Pengenalan dan Penerapan Keterampilan

Khalayak sasaran dilibatkan secara langsung dalam kagiatan transfer pengetahuan dan keterampilan melalui metode Belajar sambil Melakukan (Learning by Doing).

Kegiatan ini dilaksanakan pada tanggal 17 September 2017 di Yayasan Panti Asuhan Bumi Nusantara Kota Bengkulu. Kegiatan yang dilaksanakan meliputi penyuluhan dan praktek membuat makanan hasil olahan ikan dan diikuti oleh 23 orang peserta anakanak perempuan penghuni panti asuhan Bumi Nusantara Kota Bengkulu. Materi penyuluhan meliputi manfaat mengolah ikan menjadi aneka makanan, dan cara membuat makanan hasil olahan ikan (pempek, nugget ikan dan bakso ikan). Liflet berisi materi cara membuat makanan olahan ikan tersebut dibagikan kepada peserta kegiatan.

Evaluasi pengenalterapan keterampilan dilakukan dengan cara mengajukan beberapa pertanyaan dalam bentuk kuesioner, yang selanjutnya diisi/dijawab oleh peserta kegiatan. Aspek-aspek yang dievaluasi meliputi aspek produksi, aspek ekonomi dan aspek keberlanjutan di masa datang. Kegiatan dilanjutkan dengan pengisian Borang Evaluasi. Borang Evaluasi berisi 13 pernyataan tentang persepsi atau penilaian peserta tentang materi yang telah diberikan. Peserta diminta untuk memberikan pilihan sesuai dengan pernyataan yang dimaksud (Sangat Setuju (SS), Setuju (S), Tidak Setuju (TS) dan Sangat Tidak Setuju (STS)). Data yang diperoleh kemudian dianalisis dengan tabulasi frekuensi.

\section{HASIL DAN PEMBAHASAN}

Kegiatan praktek membuat aneka makanan olahan ikan berlangsung lancar dan baik. Peserta yang berjumlah 23 orang dibagi ke dalam tiga kelompok. Kelompok I membuat pempek, Kelompok II membuat nugget ikan dan Kelompok III membuat bakso ikan. Namun semua peserta dapat ikut pula di kelompok lain, sehingga dapat menguasai cara pembuatan aneka makanan tersebut.

\section{Kegiatan Penyuluhan dan Praktek (Learning by Doing)}
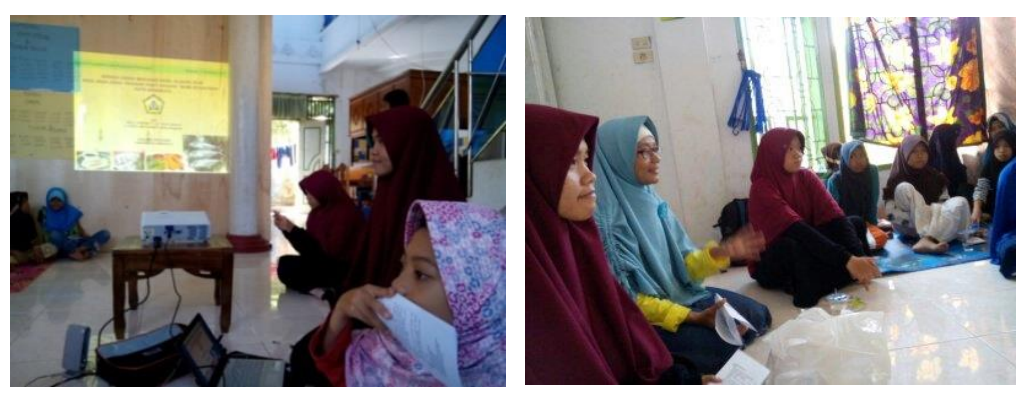
56 Dharma Raflesia Unib Tahun XVI, Nomor 1 Juni 2018
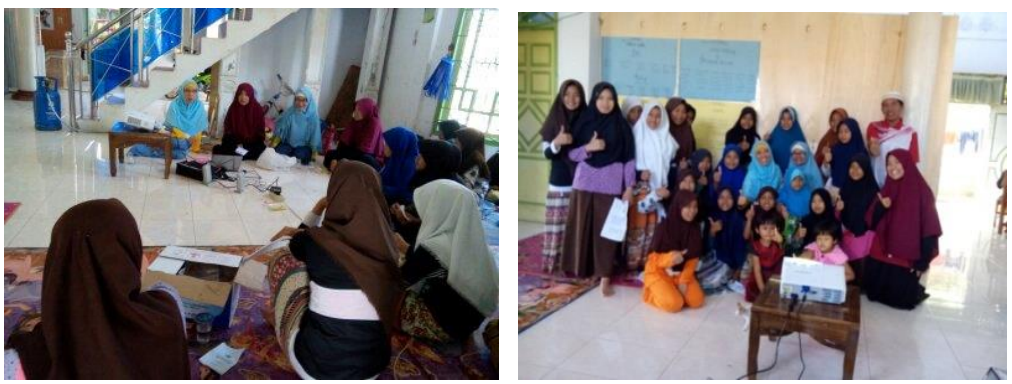

Gambar 1. Kegiatan Penyuluhan
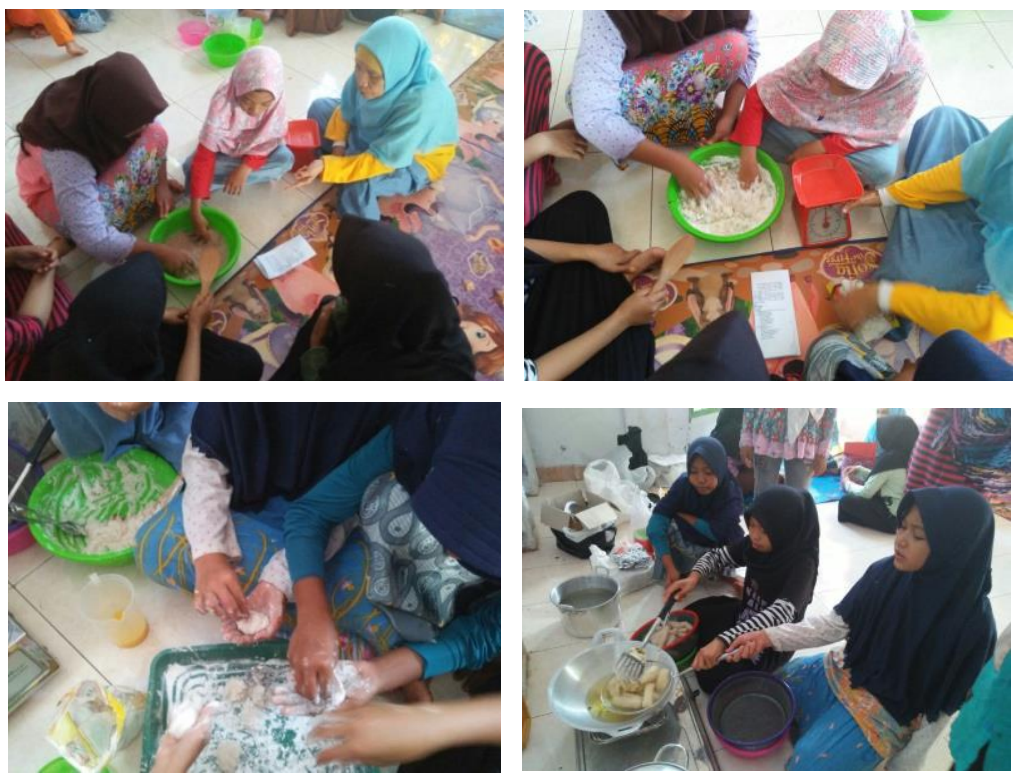

Gambar 2. Membuat Pempek
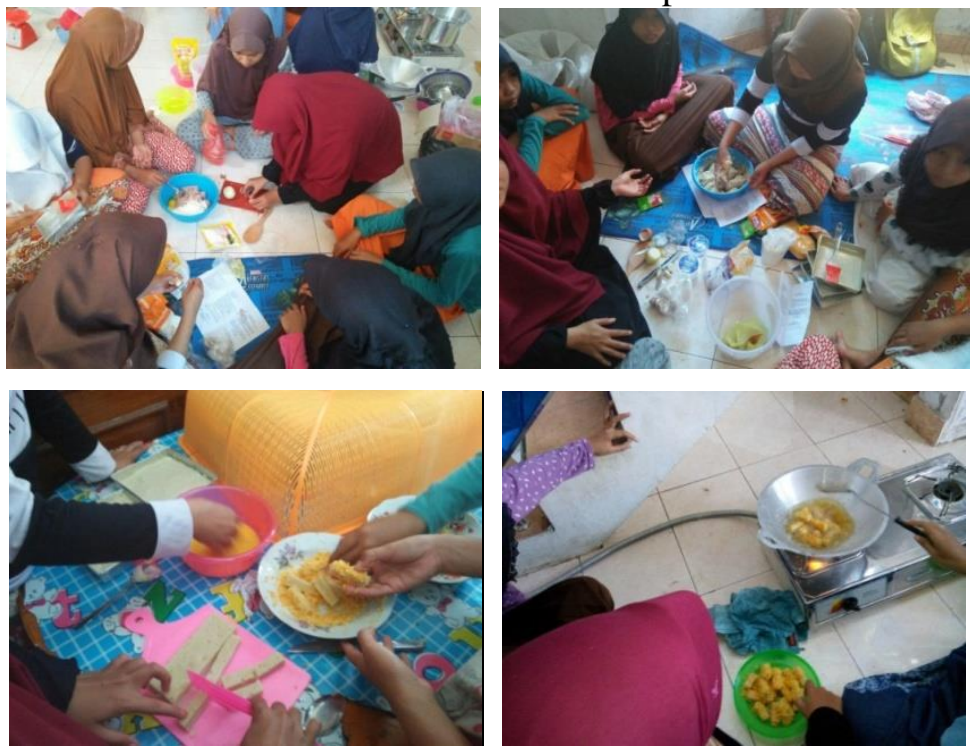

Gambar 3. Membuat Nugget Ikan 

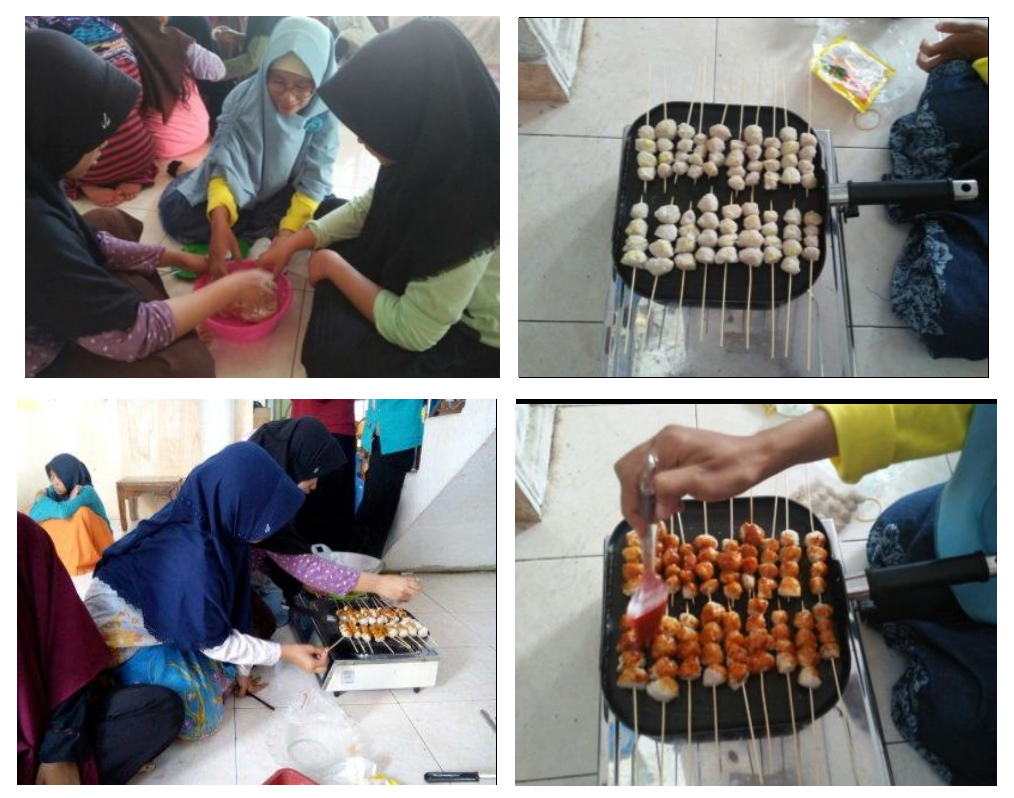

Gambar 4. Membuat Bakso Ikan

\section{Evaluasi Kegiatan Pengenalterapan Ilmu Pengetahuan dan Keterampilan}

Ilmu pengetahuan, keterampilan dan teknologi haruslah tepat guna dan bermanfaat bagi masyarakat. Pengetahuan dan teknologi yang dikenalterapkan haruslah disesuaikan dengan kondisi masyarakat sasaran, yakni meliputi aspek teknis, sosial, budaya, keetisan, politik dan ekonomi (Kurniawati, 2016).

Pelaksanaan kegiatan pengenalterapan keterampilan ini berlangsung dengan lancar dan berdampak positif bagi para peserta. Hal ini tercermin dari hasil evaluasi para peserta didasarkan pada instrumen penilaian pelaksanaan kegiatan pengabdian yang dibagikan setelah kegiatan berlangsung. Penilaian para peserta dikategorikan ke dalam tiga aspek, yakni: aspek teknis/produksi, aspek ekonomi, dan aspek peluang keberlanjutan di masa depan. Berikut adalah hasil penilaian para peserta untuk setiap aspek yang dinilai:

\section{Aspek Produksi}

Sebanyak $54,4 \%$ peserta berpendapat sangat setuju dan $40 \%$ setuju terhadap aspek produksi dari kegiatan inisiasi usaha makanan hasil olahan ikan. Sisanya $(5,6 \%)$ tidak setuju. Umumnya mereka $(94,4 \%)$ menyatakan cara membuat makanan hasil olahan ikan sangat mudah untuk dilakukan. Mereka juga mengakui bahwa bahan baku utama yakni ikan, merupakan bahan yang cukup mudah didapatkan dan harganya pun terjangkau. Begitu pula dengan peralatan yang digunakan dalam proses produksi. Peralatan yang digunakan adalah alat-alat memasak keseharian. Alat-alat tersebut cukup sederhana dan dari sisi harganya tidaklah mahal. Tabel 1 menunjukkan hasil penilaian para peserta kegiatan pengabdian terhadap aspek produksi inisiasi usaha makanan hasil olehan laut pada anak-anak panti asuhan. 
Tabel 1. Penilaian Peserta terhadap Aspek Produksi

\begin{tabular}{|c|c|c|c|c|c|c|c|c|c|}
\hline \multirow{3}{*}{ No. } & \multirow{3}{*}{ Uraian } & \multicolumn{8}{|c|}{ Penilaian } \\
\hline & & \multicolumn{2}{|c|}{ SS } & \multicolumn{2}{|c|}{$\mathbf{S}$} & \multicolumn{2}{|c|}{ TS } & \multicolumn{2}{|c|}{ STS } \\
\hline & & $\begin{array}{c}\text { Jml } \\
\text { org) }\end{array}$ & $(\%)$ & $\begin{array}{c}\text { Jml } \\
\text { (org) }\end{array}$ & $(\%)$ & $\begin{array}{c}\text { Jml } \\
\text { (org) }\end{array}$ & $(\%)$ & $\begin{array}{c}\text { Jml } \\
\text { (org) }\end{array}$ & $(\%)$ \\
\hline 1 & $\begin{array}{l}\text { Membuat makanan hasil olahan ikan } \\
\text { dapat dilaksanakan karena bahan- } \\
\text { bahannya mudah didapatkan }\end{array}$ & 11 & 61,1 & 7 & 38,9 & 0 & 0,0 & 0 & 0,0 \\
\hline 2 & $\begin{array}{l}\text { Membuat makanan hasil olahan ikan } \\
\text { dapat dilaksanakan karena harga bahan- } \\
\text { bahannya terjangkau }\end{array}$ & 10 & 55,6 & 6 & 33,3 & 2 & 11,1 & 0 & 0,0 \\
\hline 3 & $\begin{array}{l}\text { Membuat makanan hasil olahan ikan } \\
\text { dapat dilaksanakan karena alat-alatnya } \\
\text { sederhana }\end{array}$ & 8 & 44,4 & 10 & 55,6 & 0 & 0,0 & 0 & 0,0 \\
\hline 4 & $\begin{array}{l}\text { Membuat makanan hasil olahan ikan } \\
\text { dapat dilaksanakan karena harga alat- } \\
\text { alatnya terjangkau }\end{array}$ & 7 & 38,9 & 8 & 44,4 & 3 & 16,7 & 0 & 0,0 \\
\hline 5 & $\begin{array}{l}\text { Cara membuat makanan hasil olahan } \\
\text { ikan mudah dilakukan }\end{array}$ & 13 & 72,2 & 5 & 27,8 & 0 & 0,0 & 0 & 0,0 \\
\hline & Rata-rata & & 54,4 & & 40 & & 5,6 & & $\mathbf{0}$ \\
\hline
\end{tabular}

\section{Aspek Ekonomi}

Kegiatan inisiasi usaha makanan hasil olehan laut pada anak-anak panti asuhan dinilai mampu memberikan dampak positif sebagai salah satu usaha ekonomi yang dapat dikembangkan di panti asuhan Yayasan Bumi Nusantara. Hasil evaluasi menunjukkan bahwa seluruh peserta kegiatan menyetujui hasil olahan ikan yang dibuat akan disukai dan layak untuk dijual. Selain rasa yang enak, hasil olahan ikan ini juga sehat dan menyehatkan karena tidak menggunakan bahan penyedap atau pengawet buatan. Peserta juga menilai bahwa dalam perhitungan harga pokok produksi dan harga pokok penjualan untuk setiap produk yang dihasilkan dapat dihitung dengan mudah. Dengan diinisiasinya usaha makanan hasil olahan ikan ini diharapkan pihak panti asuhan memiliki alternatif sumber pendapatan dalam membantu pengelolaan biaya keseharian anak-anak panti asuhan. Tabel 2 menunjukkan hasil penilaian para peserta kegiatan pengabdian terhadap aspek ekonomi inisiasi usaha makanan hasil olehan laut pada anak-anak panti asuhan. Dari seluruh peserta kegiatan, peserta yang sangat setuju sebanyak 73,6\% dan yang setuju sebanyak 26,4\% bahwa usaha pengolahan ikan ini akan menguntungkan. Dengan demikian sebanyak $100 \%$ peserta menyatakan usaha pengolahan ikan ini layak dan menguntungkan secara ekonomis.

Tabel 2. Penilaian Peserta terhadap Aspek Ekonomi

\begin{tabular}{|c|c|c|c|c|c|c|c|c|c|}
\hline \multirow{3}{*}{ No. } & \multirow{3}{*}{ Uraian } & \multicolumn{8}{|c|}{ Penilaian } \\
\hline & & \multicolumn{2}{|c|}{ SS } & \multicolumn{2}{|c|}{$\mathbf{S}$} & \multicolumn{2}{|c|}{ TS } & \multicolumn{2}{|c|}{ STS } \\
\hline & & $\begin{array}{c}\text { Jml } \\
\text { (org) }\end{array}$ & $(\%)$ & $\begin{array}{c}\text { Jml } \\
\text { (org) }\end{array}$ & $(\%)$ & $\begin{array}{r}\text { Jml } \\
\text { (org) }\end{array}$ & $(\%)$ & $\begin{array}{c}\text { Jml } \\
\text { (org) }\end{array}$ & $(\%)$ \\
\hline 1 & $\begin{array}{l}\text { Makanan hasil olahan ikan yang } \\
\text { dibuat rasanya enak dan } \\
\text { menyehatkan }\end{array}$ & 14 & 77,8 & 4 & 22,2 & 0 & 0,0 & 0 & 0,0 \\
\hline 2 & $\begin{array}{l}\text { Makanan hasil olahan ikan yang } \\
\text { dibuat akan disukai dan layak untuk } \\
\text { dijual }\end{array}$ & 13 & 72,2 & 5 & 27,8 & 0 & 0,0 & 0 & 0,0 \\
\hline 3 & $\begin{array}{l}\text { Harga Pokok Produksi dan Harga } \\
\text { Pokok Penjualan dapat dihitung } \\
\text { dengan mudah }\end{array}$ & 10 & 55,6 & 8 & 44,4 & 0 & 0,0 & 0 & 0,0 \\
\hline 4 & $\begin{array}{l}\text { Kegiatan membuat makanan hasil } \\
\text { olahan ikan dapat menjadi usaha } \\
\text { ekonomi yang dapat dikembangkan } \\
\text { di panti }\end{array}$ & 16 & 88,9 & 2 & 11,1 & 0 & 0,0 & 0 & 0,0 \\
\hline & Rata-rata & & 73,6 & & 26,4 & & 0,0 & & $\mathbf{0 , 0}$ \\
\hline
\end{tabular}




\section{Aspek Peluang Keberlanjutan di Masa Depan}

Salah satu tujuan jangka panjang dari pelaksanaan kegiatan pengabdian ini adalah membentuk kemandirian panti asuhan baik secara pengelolaannya maupun dari sisi pemberdayaan sumber daya manusianya. Diharapkan di masa depan, panti asuhan Bumi Nusantara mampu mandiri, bisa menghidupi dirinya sendiri dan tidak hanya tergantung dari dukungan para donatur atau bantuan pemerintah semata. Bagi para penghuni panti asuhan, diharapkan melalui kegiatan ini mampu menjadi lifeskill untuk bisa mandiri di masa depannya. Peluang keberlanjutan kegiatan ini di masa depan cukup terbuka lebar. Hal ini dapat dilihat dari harapan dan komitmen para peserta untuk mewujudkannya dalam usaha kecil rumahan yang dikelola oleh pihak panti asuhan sendiri.

Hasil penilaian para peserta menunjukkan bahwa $55,6 \%$ persen peserta sangat setuju dan yang menyatakan setuju $(44,4 \%)$, sehingga $100 \%$ peserta bersedia mendukung dan berpartisipasi aktif dalam usaha membuat makanan hasil olahan ikan di panti asuhan. Mereka juga berkomitmen untuk mengusulkan ke pengurus panti agar mewujudkan usaha tersebut. Selain bernilai positif, usaha membuat makanan hasil olahan ikan ini dapat menjadi kegiatan untuk mengisi waktu luang para penghuni panti asuhan. Tabel 3 menunjukkan hasil penilaian para peserta kegiatan pengabdian terhadap aspek peluang keberlanjutan di masa depan dalam inisiasi usaha makanan hasil olehan laut pada anakanak panti asuhan.

Tabel 3. Penilaian Peserta terhadap Aspek Peluang Keberlanjutan di Masa Depan

\begin{tabular}{|c|c|c|c|c|c|c|c|c|c|}
\hline \multirow{3}{*}{ No. } & \multirow{3}{*}{ Uraian } & \multicolumn{8}{|c|}{ Penilaian } \\
\hline & & \multicolumn{2}{|c|}{ SS } & \multicolumn{2}{|c|}{$\mathbf{S}$} & \multicolumn{2}{|c|}{ TS } & \multicolumn{2}{|c|}{ STS } \\
\hline & & $\begin{array}{c}\text { Jml } \\
\text { (org) }\end{array}$ & $(\%)$ & $\begin{array}{l}\text { Jml } \\
\text { (org) }\end{array}$ & $(\%)$ & $\begin{array}{c}\text { Jml } \\
\text { (org) }\end{array}$ & $(\%)$ & $\begin{array}{l}\text { Jml } \\
\text { (org) }\end{array}$ & $(\%)$ \\
\hline 1 & $\begin{array}{l}\text { Kegiatan membuat makanan hasil } \\
\text { olahan ikan merupakan kegiatan } \\
\text { positif untuk mengisi waktu luang }\end{array}$ & 16 & 88,9 & 2 & 11,1 & 0 & 0,0 & 0 & 0,0 \\
\hline 2 & $\begin{array}{l}\text { Membuat makanan hasil olahan } \\
\text { ikan tidak bertentangan dengan } \\
\text { peraturan-peraturan panti dan } \\
\text { norma-norma di masyarakat }\end{array}$ & 12 & 66,7 & 6 & 33,3 & 0 & 0,0 & 0 & 0,0 \\
\hline 3 & $\begin{array}{l}\text { Saya akan mengusulkan ke } \\
\text { pengurus panti agar mewujudkan } \\
\text { usaha membuat makanan hasil } \\
\text { olahan ikan }\end{array}$ & 6 & 33,3 & 12 & 66,7 & 0 & 0,0 & 0 & 0,0 \\
\hline 4 & $\begin{array}{l}\text { Saya akan mendukung dan } \\
\text { berpartisipasi aktif dalam usaha } \\
\text { membuat makanan hasil olahan } \\
\text { ikan }\end{array}$ & 6 & 33,3 & 12 & 66,7 & 0 & 0,0 & 0 & 0,0 \\
\hline & Rata-rata & & 55,6 & & $\mathbf{4 4 , 4}$ & & $\begin{array}{l}\mathbf{0 , 0} \\
\end{array}$ & & 0,0 \\
\hline
\end{tabular}

\section{KESIMPULAN DAN SARAN}

\section{Kesimpulan}

Kegiatan penyuluhan dan praktek "Inisiasi Usaha Makanan Hasil Olahan Ikan pada Anak-anak Yayasan Panti Asuhan Bumi Nusantara Kota Bengkulu" berlangsung lancar dan baik. Peserta atau khalayak sasaran, yakni anak-anak penghuni panti dengan antusias mengikuti semua tahap kegiatan.

Evaluasi yang dilakukan terhadap kegiatan inisiasi usaha pengolahan ikan ini menunjukkan bahwa ilmu dan keterampilan yang dikenalterapkan, yakni dari aspek produksi (mudah dilakukan) dinyatakan oleh $94,4 \%$ peserta, dari aspek ekonomi (layak dan menguntungkan) dinyatakan oleh $100 \%$ peserta, dan dari aspek keberlanjutan di masa 
60 Dharma Raflesia Unib Tahun XVI, Nomor 1 Juni 2018

depan (inisiasi usaha ini dicita-citakan untuk diwujudkan menjadi usaha panti) dinyatakan oleh $100 \%$ peserta.

\section{Saran}

Jenis-jenis olahan ikan lainnya diharapkan juga dapat dikenal dan diterapkan. Hasil kegiatan ini diharapkan akan mewujudkan suatu usaha ekonomi produktif bagi anak-anak panti. Cara-cara pemasaran produk yang dihasilkan juga harus dipilih dan dikembangkan.

\section{DAFTAR PUSTAKA}

http://gizi.depkes.go.id, 2013, Ikan untuk Ketahanan Pangan dan Gizi Nasional, Bagian II, Diakses Tanggal 27 Maret 2017 Pukul 14.58 WIB.

http://infoagribisnis.com, 2017, Alternatif Peluang Usaha Olahan Ikan Laut Ini Wajib Anda Coba, Diakses Tanggal 3 Nopember 2017 Pukul 11.50 WIB.

Khoirunnisa, Sella, Ishartono, dan Risna Resnawaty, 2015, Pemenuhan Kebutuhan

Pendidikan Anak Asuh Di Panti Sosial Asuhan Anak, Prosiding Penelitian dan Pengabdian Kepada Masyarakat, 2(1): 69-73.

Kurniawati, Adelya Desi, 2016, Teknologi Tepat Guna. http://adelyadesi.lecture.ub.ac.id. Diakses Tanggal 12 Januari 2018 Pukul 10.00 WIB.

Putry, 2016, Manfaat Mengonsumsi Ikan bagi Kesehatan, http://disehat.com, Diakses Tanggal 12 April 2017 Pukul 12.30 WIB. 